\title{
Analysis of Elementary School Teachers' Ability in Using ICT Media and Its Impact on the Interest to Learn of Students in Banda Aceh
}

\author{
Yusrizal $^{1}$, Ibnu Hajar ${ }^{2}$, Samsidar Tanjung ${ }^{2}$ \\ ${ }^{1}$ Postgraduate Student in Universitas Negeri Medan, Indonesia \\ ${ }^{2}$ Lecturer in Universitas Negeri Medan, Indonesia \\ yusrizalr2@gmail.com
}

\begin{abstract}
This study aims to determine: 1) Primary School Teachers' Ability in utilizing ICTbased learning media in Banda Aceh City; and 2) Differences in the average of students interest in learning taught by high, medium and low competence teachers in utilizing ICT-based learning media.This research is conducted in Banda Aceh City. The population in this study are public elementary schools equipped with wifi and at least B accredited consisting of 42 schools. The research method used is a quantitative method with a comparative type. Data collection techniques ae carried out by observation techniques, and questionnaires. The data analysis technique in this study uses one-way ANAVA. The results of the study show that: (1) The ability of elementary school teachers to utilize ICT-based learning media in Banda Aceh is in the medium category. (total score $=170.22$, this is in the range $140 \leq X<220$ ); and (2) There is a significant difference between the average of students interest in learning taught by high, medium and low competence teachers in utilizing ICT-based learning media. $(F$ count $=$ 40,205 with sig. $=0,000<0,05$ ).
\end{abstract}

Keywords : teacher competence; learning media; learning interest

\section{Introduction}

The main key to the success of education in a country lies in the quality of teachers possessed in the country. The teacher is an important factor in determining the direction and purpose of education. A learning will be good if you have a qualified teacher. In other words, the better the quality of teachers in a country, the better the quality of education in that country. Therefore, a teacher must be able to manage the learning process so that students are interested and motivated to learn so that the quality of learning is good (Adyatma, 2017). The first education a child passes through and receives is education in the family. Children tend to be anything that is heard, seen, experienced and taught by their parents, both knowledge, skills, the formation of behavioral attitudes, everything that is accepted, possibly all that is in the family will continue to be practiced outside the home or social environment (Mardhatillah, 2018). the right step that can be done by the teacher is to change the learning pattern by incorporating elements of technology as a tool in the learning process given the rapid development of technology today. Miarso (2005) said that factors that influence the realization of quality learning processes in an effort to achieve educational goals, one of which is the use of ICT as a tool in the learning process. Bataineh (2018) says that ICT students are not only active in the teaching and learning process but also active in the collaborative process, visual enhancement, so that learning can be student-centered. In this case, the teacher is responsible for improving student learning outcomes, one of the ways that can be taken is by creating active teaching and learning activities and indirectly can increase student learning interest.

Learning activities in schools are the main activities in improving the quality of national education. Through the teaching and learning process it is expected to achieve educational goals in the form of changes in students' behavior. This learning process requires language to 
enable people to interact and communicate with each other, share experiences, learn from others, and improve their intellectuality (Anzar \& Mardhatillah, 2018)

Media has an important role in a learning process, with the media students can easily understand the material being taught. ICT is here to answer it all, with the help of ICT, teachers can easily design or even directly access the media from the internet in the form of videos and images that are relatively more practical and effective compared to conventional media. The use of ICT in learning can lead to changes in the teaching and learning process (Mbodila et al, 2013). In this regard, Mayer (2009: 93) said that students who learn with media are a combination of words and images better than just using words. This shows that the importance of ICT is used in learning so that it can indirectly foster children's interest in learning material through the media used by the teacher. In line with that, Halidi (2015: 58) said that learning using ICT can increase students' interest in learning. Larlen (2012) in his research said that the use of technology as a learning media can increase learning interest especially in learning to read.

Based on Dapodik data in 2019 it can be seen that Elementary Schools in the Banda Aceh City Government, both public and private, which use as many as 51 schools, and public and private elementary schools that do not use wifi are as many as 35 schools. Thus it is clear that the government has been endeavoring and will continue to strive to improve the various ICT facilities needed in each school. In addition to data dapodik, the same thing is also shown from the results of observations and interviews with several elementary school teachers in Banda Aceh City. From these data, it can be seen that some schools have been equipped with ICT facilities such as laptops, computers, internet services (wifi), Infocus. But in this case there are still teachers who do not understand using these facilities as learning media. Some of them still use conventional media such as cartons, and objects in the surrounding environment as media in the learning process. Even if the teacher understands how to use ICT as a learning media the benefits are far greater than conventional media. Sudatha (2014: 25) says the use of ICT in learning can improve the quality of learning where students can think critically, improve skills, cooperate, and build interactions between groups. Sudhata (2014: 25) adds several reasons for ICT to be applied in learning, including: 1) ICT can change the learning paradigm that was originally teacher-centered now to be student-centered, 2) ICT learning model is an active and collaborative learning model; and 3) ICT can increase motivation, skills, thinking structures, and in learning more actively communicate electronically.

\section{Review of Literature}

\subsection{Teacher Competence in Utilizing ICT}

Competence is the ability to use knowledge and skills (Blaskova, 2014). In another opinion Sumiarsi (2015) says that competence is a rational behavior to achieve the required goals according to the expected conditions. According to Permendiknas Number 16 of 2007, teacher competence in utilizing ICT has at least two functions, namely ICT as self-development and ICT as a support in the learning process (Batubara, 2017). Therefore, besides having the ability to teach teachers must also be able integrating ICT utilization as a medium in the learning process. Batubara (2017) added that teacher competency in the ICT sector which has become a recent concern include mastering basic applications, government policies on the use of ICT in schools, principles and design of ICT-based teaching materials development, and procedures for using ICT hardware and software as media in class . Munir (2014: 11) 
formulates six aspects of ICT-based teacher professional work, including: 1) Understanding ICT in education; 2) Understanding the curriculum and assessment; 3) Mastering pedagogy; 4) Mastering ICT; 5) Understanding organization and administration; and 7) Teacher professional learning. In addition, UNESCO (in Batubara, 2017) said the dimensions of teacher competency regarding ICT according to the UNESCO framework consisted of six parts, namely: 1) Understanding of government policies related to the rules of ICT use in education; 2) Utilization of ICT in reviewing curriculum and assessment; 3) Use of ICT on pedagogical aspects; 4) Mastery of ICT-based equipment and materials; 5) Understanding of the ethics of using ICT in organizational and administrative management; and 6) Use of ICT in improving teacher professionalism

From the opinions above, an indicator can be formulated that can be used to measure the level of teacher competence in utilizing ICT as a learning media. The formulation of these indicators can be seen in the following table.

Table 1. Category of Teacher Competency Assessment Using ICT

\begin{tabular}{|c|c|c|c|c|}
\hline \multicolumn{4}{|c|}{ ICT Based Learning Media } & \multirow{2}{*}{ Category } \\
\hline Computer Usage & Powerpoint Usage & Tutorial video & Internet & \\
\hline $\begin{array}{l}\text { Turn on and turn } \\
\text { off the computer }\end{array}$ & Open powerpoint & Open closed video & $\begin{array}{l}\text { Connect your PC to } \\
\text { the internet }\end{array}$ & \multirow{2}{*}{ Low } \\
\hline $\begin{array}{l}\text { Open and close } \\
\text { files }\end{array}$ & $\begin{array}{l}\text { Hesitate to use } \\
\text { powerpoint }\end{array}$ & $\begin{array}{l}\text { Speed up or pause } \\
\text { the video }\end{array}$ & $\begin{array}{l}\text { Hesitate to use the } \\
\text { internet }\end{array}$ & \\
\hline $\begin{array}{l}\text { Copy (back-up) } \\
\text { data }\end{array}$ & $\begin{array}{l}\text { Designing } \\
\text { powerpoints with a } \\
\text { minimum }\end{array}$ & $\begin{array}{l}\text { Copying videos } \\
\text { from one disk to } \\
\text { another }\end{array}$ & $\begin{array}{l}\text { Open Google, and } \\
\text { YouTube }\end{array}$ & \multirow{2}{*}{ Medium } \\
\hline $\begin{array}{l}\text { Delete files and } \\
\text { create folders }\end{array}$ & $\begin{array}{l}\text { Use a background } \\
\text { that matches the } \\
\text { writing color }\end{array}$ & $\begin{array}{l}\text { Display via } \\
\text { YouTube }\end{array}$ & $\begin{array}{l}\text { Download teaching } \\
\text { materials, media } \\
\text { from the internet }\end{array}$ & \\
\hline $\begin{array}{l}\text { Connect a } \\
\text { computer to the } \\
\text { internet }\end{array}$ & $\begin{array}{l}\text { Design interesting } \\
\text { powerpoints }\end{array}$ & $\begin{array}{l}\text { Download via the } \\
\text { internet }\end{array}$ & $\begin{array}{l}\text { Looking for various } \\
\text { sources of } \\
\text { information } \\
\text { (journals, articles, } \\
\text { etc.) }\end{array}$ & \multirow{2}{*}{ High } \\
\hline $\begin{array}{l}\text { Installation } \\
\text { program }\end{array}$ & $\begin{array}{l}\text { Designing } \\
\text { multimedia } \\
\text { presentations }\end{array}$ & $\begin{array}{l}\text { Design your own } \\
\text { learning video }\end{array}$ & $\begin{array}{l}\text { Actively use email, } \\
\text { blogs, social media } \\
\text { to exchange } \\
\text { information }\end{array}$ & \\
\hline
\end{tabular}

\subsection{Learning Media Based Information and Communication Technology}

Media is everything that brings information from sources to recipients of information (Smaldino et al., 2014: 7). In another opinion Schramm (1907: 4) says media is a messenger technology that can be used for learning purposes. Media as one component in learning is a sub-system whose existence cannot be released in the learning process (Tanjung, 2015). While Information Communication and Technology is a container that is used to process, process and present data or information by making computers as brains in their operation. Thus it can be concluded that ICT-based learning media is to make technology as a tool used for the process of delivering information in the form of knowledge from an educator (message provider) to students (recipients) so that learning objectives are achieved. 
Rusman, et al (2015: 181) divided the media into three groups including: 1) Audio media, namely media that can only be heard; 2) Visual media, namely media that can only be seen as not containing sound elements; 3) Audio-visual media, which is a type of media that contains elements of sound that also contain elements of images that can be seen. The information from Information Communication and Technology (ICT) Ritonga (2017) argues that ICT-based learning media are internet, PowerPoint, e-learning, e- mail, and learning CDs. In addition, Rosdiana (2016) said ICT-based learning media were divided into three categories: 1) Computer technology; 2) multimedia technology; 3) Computer and computer technology. In another opinion Rusman, et al. (2015) said that ICT-based learning media were among them; 1) Learning based on computers; 2) Learning through TV / video; 3) Blended learning; 4) elearniing; 5) Learning based on Powerpoint; 6) Learning based on computer networks. Furthermore, Mayer (2009) divides the five stages in multimedia messaging, namely; 1) choose the words that are relevant to the subject of the narration presented;2) choose pictures that are relevant from the illustrations presented; 3) arrange selected words in a coherent verbal representation; 4) arrange the images presented in a coherent visual representation; and 5) combining verbal representations and visual representations in parallel. From some of the opinions above, it can be concluded that ICT-based media that can be utilized by teachers as a medium for learning at the elementary level include the following: 1) Computers / Notebooks; 2) Microsoft Office PowerPoint; 3) Interactive Multimedia; 4) Learning Videos; and 5) Internet.

\subsection{Interest in Learning}

Interest is a feeling of attraction, attention, more desire that is possessed by a person towards things, without deviations. The intention will be to settle and develop on his own to obtain the support of his environment that has experience. According to Ahmadi (2009: 148) interest is the attitude of a person's soul including his or her cognitive functions (cognition, communication, and emotion), which is determined in terms of strong relationships of feelings. According to Slameto (2003: 180) interest is a fixed tendency to pay attention and remember some activities. Whereas according to Djaali (2008: 121) interest is a feeling of being more like and feeling interested in something or activity, without anyone telling.

Crow \& Crow (in Djaali, 2008: 121) says that "interest is related to the style of motion that encourages a person to deal with or deal with people, objects, activities, experiences that are stimulated by the activity itself". While learning is a change in students in the form of knowledge, skills and behavior as a result of interaction with the environment. Thus it is concluded that the notion of interest in learning is the tendency of individuals to have pleasure without any coercion that can cause changes in knowledge, skills and behavior. According to Djamarah (2002: 132) indicators of interest in learning are feeling like / happy, statements prefer, there is a sense of interest in the awareness to learn without being told, participating in learning activities, giving attention. According to Slameto (2010: 180) some indicators of interest in learning namely: feelings of pleasure, attraction, acceptance, and student involvement.

\section{Research Method}

The approach used in this study was a quantitative approach with comparative analysis techniques. Comparative analysis was used to identify differences in the average learning 
interest of students taught by high, medium, and low competent teachers in utilizing ICT-based learning media. This research was conducted in Banda Aceh City from March to April 2019. The population in this study were Public Elementary Schools that had used wifi as many as 42 schools. The sampling technique in this study was using purposive sampling. Considering that the research sample taken was at least B accredited schools and had implemented the 2013 curriculum. Thus the number of samples obtained was as many as 9 schools. Data collection techniques used in this study were observation and questionnaire techniques. Observation techniques are used to see the level of ability of teachers in utilizing ICT-based learning media. While the learning interest questionnaire is used to measure the level of interest in student learning that is taught with the media used by the teacher.

The data analysis technique used in this study was descriptive and inferential statistical techniques. Descriptive statistics are used to describe teacher competency data in utilizing ICTbased learning media which are then categorized by teacher abilities based on ability level. While inferential statistical techniques used in this study are comparative techniques by comparing student learning interests based on the level of the teacher's ability to use ICT as a learning medium. Testing the hypothesis was carried out by One Way Anova test with a significant level of 0.05. Before the One Way Anova test was conducted, the analysis requirements test was carried out first, namely the normality test and the data homogeneity test. The normality test was carried out by the Kolmogorov-Smirnov test while the data homogeneity test was carried out by the Levene test with a significant level of 0.05 .

\subsection{Description of Research Data}

\section{Result}

A. Teacher Competence Utilizing ICT as a Learning Media in Banda Aceh City

Based on observations, it was known that the ability of teachers to use ICT as a learning media in Banda Aceh City could be seen in the following table.

Table 2. Total Score of Teacher Ability Score Using ICT-Based Learning Media

\begin{tabular}{|c|l|c|c|}
\hline \multicolumn{1}{|c|}{ Indicator } & Item & $\begin{array}{c}\text { Total } \\
\text { Score }\end{array}$ \\
\hline 1 & The ability to use a laptop & 19 & 58,78 \\
\hline 2 & The ability to use powerpoint & 18 & 49,78 \\
\hline 3 & The ability to use tutorial video & 9 & 26,78 \\
\hline 4 & The ability to use internet & 14 & 34,89 \\
\hline \multicolumn{2}{r|}{ Total } & $\mathbf{6 0}$ & $\mathbf{1 7 0 , 2 2}$ \\
\hline
\end{tabular}

To be more clear, below was presented visually the ability of teachers to utilize ICTbased learning media in Banda Aceh City. 


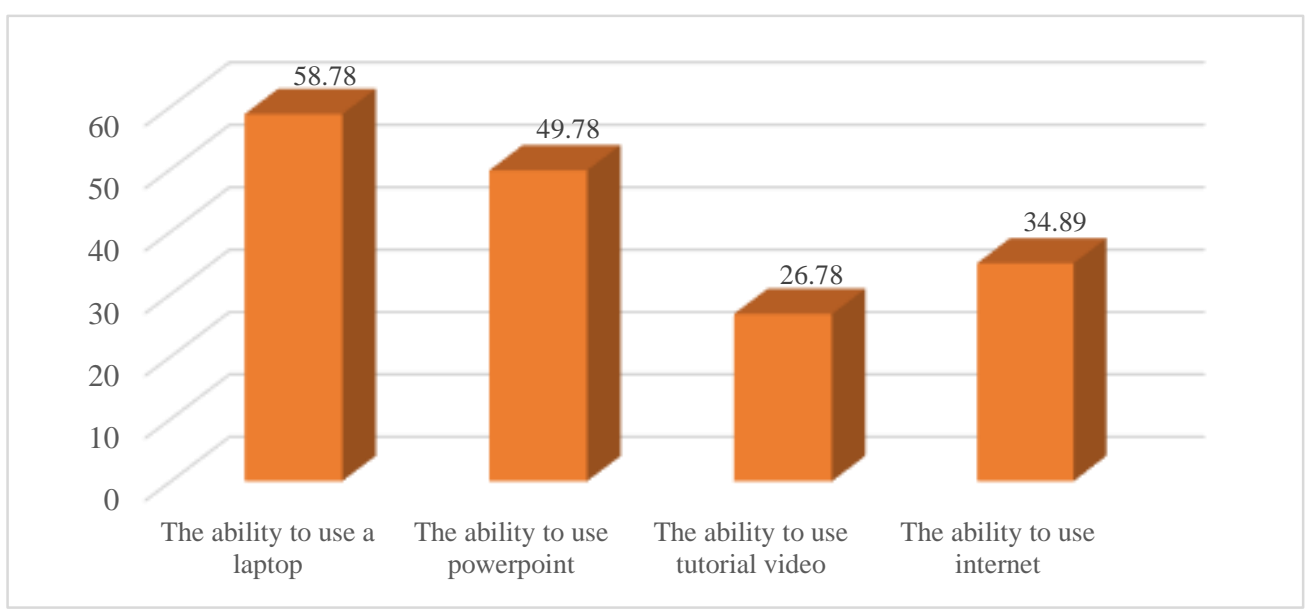

Figure 1 Teacher's Ability Histogram Using ICT-Based Learning Media in Banda Aceh City

Table 3. Category of Teacher Capabilities Using ICT-Based Learning Media

\begin{tabular}{|c|c|}
\hline Category & Score \\
\hline Low & $\mathrm{X}<140$ \\
\hline Medium & $140 \leq \mathrm{X}<220$ \\
\hline High & $220 \leq \mathrm{X}$ \\
\hline
\end{tabular}

Based on table 3, it was found that the teacher's ability score was 170.22 . This value is between $140 \leq X<220$. Thus, it can be concluded that the ability of teachers to use ICT-based learning media in Banda Aceh City is classified as moderate.

B. Categorization of Teacher's Capabilities in Utilizing ICT-Based Learning Media in Banda Aceh City

The categorization of teachers' abilities in utilizing ICT-based learning media in each Public Elementary School (SDN) in Banda Aceh City can be seen in the table below.

Table 4. Teacher's Ability in Each Elementary School in Banda Aceh City

\begin{tabular}{|c|c|c|c|c|c|c|c|c|c|c|c|}
\hline \multirow{2}{*}{ No } & \multirow{2}{*}{ Indicator } & \multirow{2}{*}{ Item } & \multicolumn{9}{|c|}{ School } \\
\hline & & & SD & $\begin{array}{c}\text { SD } \\
16\end{array}$ & $\begin{array}{l}\text { SD } \\
28\end{array}$ & $\begin{array}{l}\text { SD } \\
29\end{array}$ & $\begin{array}{l}\text { SD } \\
38\end{array}$ & $\begin{array}{l}\text { SD } \\
42\end{array}$ & $\begin{array}{c}\text { SD } \\
\mathbf{5 0}\end{array}$ & $\begin{array}{c}\text { SD } \\
51\end{array}$ & $\begin{array}{l}\text { SD } \\
60\end{array}$ \\
\hline 1 & The ability to use a laptop & 19 & 85 & 87 & 55 & 34 & 53 & 44 & 89 & 54 & 28 \\
\hline 2 & The ability to use powerpoint & 18 & 75 & 62 & 50 & 37 & 47 & 40 & 75 & 44 & 18 \\
\hline 3 & $\begin{array}{l}\text { The ability to use tutorial } \\
\text { video }\end{array}$ & 9 & 40 & 37 & 28 & 16 & 26 & 17 & 41 & 26 & 10 \\
\hline 4 & The ability to use internet & 14 & 52 & 43 & 39 & 19 & 35 & 17 & 59 & 34 & 16 \\
\hline & Total & 60 & 252 & 229 & 172 & 106 & 161 & 118 & 264 & 158 & 72 \\
\hline
\end{tabular}


Based on the table above, it can be described as follows: (1) The number of ability scores obtained by teachers of Public Elementary School (SDN) 8 is 252, this value is in the range of $220 \leq X$. Thus the ability of teachers of SDN 8 is high; (2) The number of ability scores obtained by the teacher of SDN 16 is 229 , this value is in the range of $220 \leq X$. Thus the ability of SDN 16 teachers is high; (3) The number of ability scores obtained by the teacher of SDN 28 is 172 , this value is in the range between $140 \leq X<220$. Thus the ability of SDN 28 teachers is classified as moderate; (4) The number of ability scores obtained by elementary school teachers SDN 29 is 106, this value is in the range $X<140$. Thus the ability of SDN 29 is low; (5) The number of ability scores obtained by teachers of SDN 38 is 161 , this value is in the range between $140 \leq X<220$. Thus the ability of teachers of Public SDN 38 is classified as moderate; (6) The number of ability scores obtained by SDN 42 teacher is 118 , this value is in the range $X<140$. Thus the ability of SDN 42 teachers is low; (7) The number of ability scores obtained by the teachers of SDN 50 is 264 , this value is in the range of $220 \leq X$. Thus the ability of the teachers of SDN 50 is high; (8) The number of ability scores obtained by teacher at SDN 51 is 158 , this value is in the range of $140 \leq X<220$. Thus the ability of SDN 51 teachers is moderate; and (9) The number of ability scores obtained by teachers of SDN 60 is 72, this value is in the range $X<140$. Thus the ability of teachers in SDN 60 is relatively low.

Overall it can be categorized as follows: (1) Teachers with "high" abilities in utilizing ICT as learning media include: teacher in SDN 50, teacher in SDN 8, and teacher in SDN 16; (2) Teachers with "moderate" abilities in utilizing ICT as learning media include: teacher in SDN 28, teacher in SDN 38, and teacher in SDN 51; and (3) Teachers with "low" abilities in utilizing ICT as learning media include: teacher in SDN 42, teacher in SDN 29, and teacher in SDN 50. To be clearer, the categories of teacher abilities in each school can be seen in the following figure 2 .

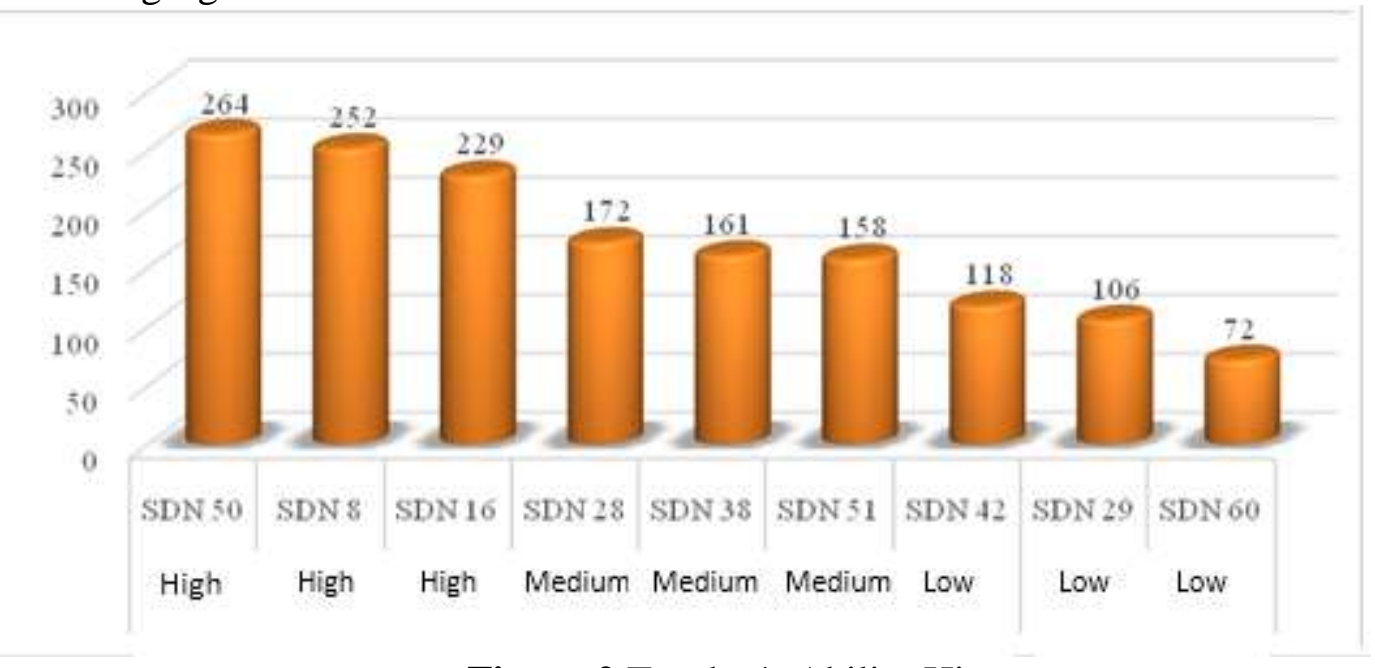

Figure 2 Teacher's Ability Histogram

C. Interest in Student Learning Taught by Highly Competent Teachers

Frequency distribution of scores on student learning interest taught by highly competent teachers in utilizing ICT-based learning media can be seen in the following table: 
Table 5 Frequency Distribution of Student Interest Taught by High-Competence Teachers

\begin{tabular}{|c|c|c|}
\hline \multicolumn{3}{|c|}{ Student Interest to Learn } \\
\hline Interval & Frequency & Percentage \\
\hline $66-70$ & 2 & $2 \%$ \\
\hline $71-75$ & 3 & $3 \%$ \\
\hline $76-80$ & 12 & $13 \%$ \\
\hline $81-85$ & 14 & $16 \%$ \\
\hline $86-90$ & 30 & $33 \%$ \\
\hline $91-95$ & 16 & $18 \%$ \\
\hline $96-100$ & 13 & $14 \%$ \\
\hline Total & $\mathbf{9 0}$ & $\mathbf{1 0 0 \%}$ \\
\hline
\end{tabular}

The frequency distribution of scores of student learning interests taught by highly competent teachers is visually shown in the form of the following histogram:

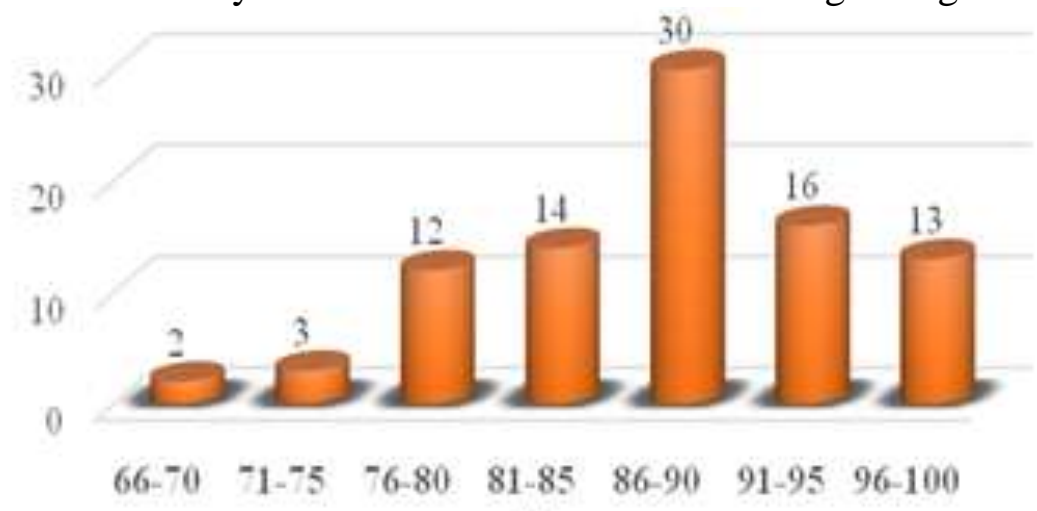

Figure 3 Histogram Students' Interest in Learning Taught by High-Competency Teachers

D. Interest in Learning and Student Learning Outcomes Taught by Teachers with Medium

Competence

Frequency distribution of scores on student learning interest taught by mediumcompetency teachers in utilizing ICT-based learning media can be seen in the following table:

Table 6 Distribution of Frequency of Student Learning Interests Taught by Teachers with Medium Competence

\begin{tabular}{|c|c|c|}
\hline \multicolumn{3}{|c|}{ Student Interest to Learn } \\
\hline Interval & Frequency & Percentage \\
\hline $66-69$ & 1 & $1 \%$ \\
\hline $70-73$ & 8 & $9 \%$ \\
\hline $74-77$ & 13 & $15 \%$ \\
\hline $78-81$ & 10 & $12 \%$ \\
\hline $82-85$ & 15 & $17 \%$ \\
\hline $86-89$ & 20 & $23 \%$ \\
\hline $90-93$ & 12 & $14 \%$ \\
\hline $94-97$ & 7 & $8 \%$ \\
\hline Total & $\mathbf{8 6}$ & $\mathbf{1 0 0 \%}$ \\
\hline
\end{tabular}


The frequency distribution of student learning interest scores taught by moderately competent teachers is visually shown in the form of the following histogram:

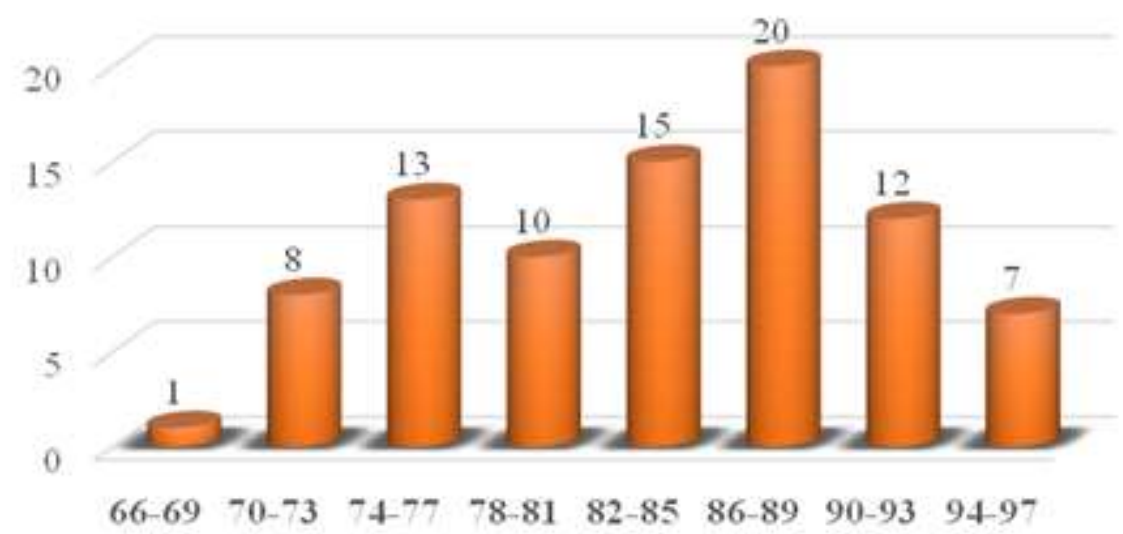

Figure 4 Histogram Student interest in learning taught by the teacher is of moderate competence

E. Interest in Learning and Student Learning Outcomes Taught by Low Competence Teachers

Frequency distribution of scores on student learning interest taught by low-competency teachers in utilizing ICT-based learning media can be seen in the following table:

Table 7 Frequency Distribution of Student Interest Taught by Low Competence Teachers

\begin{tabular}{|c|c|c|}
\hline \multicolumn{3}{|c|}{ Student Interest to Learn } \\
\hline Interval & Frequency & Percentage \\
\hline $59-63$ & 4 & $6 \%$ \\
\hline $64-68$ & 5 & $7 \%$ \\
\hline $69-73$ & 12 & $17 \%$ \\
\hline $74-78$ & 17 & $25 \%$ \\
\hline $79-83$ & 17 & $25 \%$ \\
\hline $84-88$ & 11 & $16 \%$ \\
\hline $89-93$ & 2 & $3 \%$ \\
\hline $94-98$ & 1 & $1 \%$ \\
\hline Total & $\mathbf{6 9}$ & $\mathbf{1 0 0} \%$ \\
\hline
\end{tabular}

The frequency distribution of student learning interest scores taught by low-competency teachers is visually shown in the form of the following histogram:

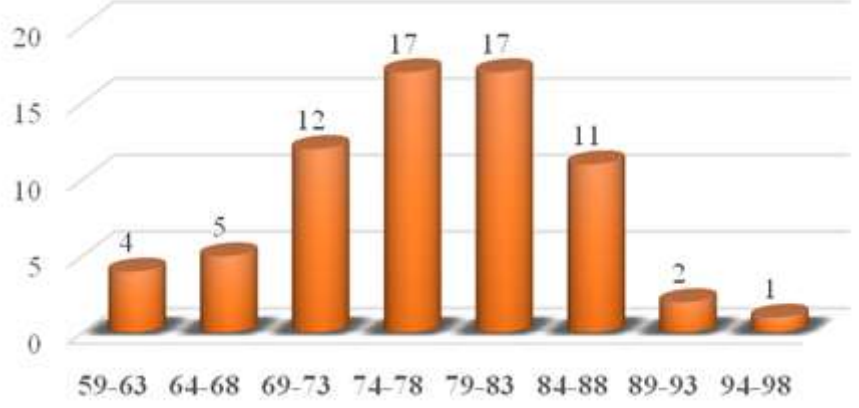

Figure 5 Histogram Student interest in learning taught by low-competency teachers 


\subsection{Test Prerequisites}

\section{A. Normality Test}

Table 8. Tests of Normality

\begin{tabular}{|l|r|r|r|r|r|r|}
\hline \multirow{2}{*}{ Category } & \multicolumn{3}{|c|}{ Kolmogorov-Smirnov $^{\mathrm{a}}$} & \multicolumn{3}{|c|}{ Shapiro-Wilk } \\
\cline { 2 - 7 } & Statistic & df & \multicolumn{1}{c|}{ Sig. } & Statistic & df & \multicolumn{1}{c|}{ Sig. } \\
\hline Interest High &, 117 & 90 &, 004 &, 973 & 90 &, 054 \\
Medium &, 097 & 86 &, 045 &, 975 & 86 &, 100 \\
Low &, 095 & 69 &, $200^{*}$ &, 976 & 69 &, 217 \\
\hline
\end{tabular}

*. This is a lower bound of the true significance.

a. Lilliefors Significance Correction

Based on the normality test table above, it can be seen that the data of high learning interest obtained sig. amounting to $0.54>0.05$ thus it can be said that the data is normally distributed. Then the data on learning interest is being obtained sig. amounting to $0.100>0.05$ thus it can be said that the data is normally distributed. Furthermore, the low learning interest data obtained sig. in the amount of $0.217>0.05$ thus it can be said that the data is normally distributed.

\section{B. Homogeneity Test}

The homogeneity test aims to find out whether the research sample is homogeneous or not. A summary of homogeneity test calculations can be seen in the following table

Table 9 Testing the Homogeneity of Student Learning Interests Taught by High, Medium and Low Competent Teachers

\section{Test of Homogeneity of Variances}

Interest to Learn

\begin{tabular}{|c|c|c|c|}
\hline Levene Statistic & df1 & df2 & Sig. \\
\hline 217 & 2 & 242 & 805 \\
\hline
\end{tabular}

Based on the table, it can be seen that testing the homogeneity of students' interest in learning taught by teachers with high, medium and low competency scores sig. amounting to $0.805>0.05$. Thus, it can be concluded that the three groups of data are relatively similar or homogeneous.

\subsection{Hypothesis Test}

Hypothesis testing of this research uses one way anovayang conducted with the help of SPSS version 23 with the level of sig. amounting to $0.05 \%$. Testing the hypothesis in this study can be seen in the following table:

Table 10 One Way Anova Test Results Interest in Student Learning Based on Teacher

Competency Level Utilizing ICT as a Learning Media

\section{ANOVA}




\begin{tabular}{|l|r|r|r|r|r|}
\hline & Sum of Squares & df & Mean Square & F & Sig. \\
\hline Between Groups & 4371,751 & 2 & 2185,875 & 40,205 &, 000 \\
Within Groups & 13157,147 & 242 & 54,368 & & \\
Total & 17528,898 & 244 & & & \\
\hline
\end{tabular}

The statistical hypothesis tested is

\section{Information:}

$$
\begin{aligned}
& \mathrm{H}_{\mathrm{o}}: \mu_{a 1}=\mu_{a 2}=\mu_{a 3} \\
& \mathrm{H}_{\mathrm{a}}: \mu_{a 1} \neq \mu_{a 2} \neq \mu_{a 3}
\end{aligned}
$$

$\mu_{a 1}$ : Average student learning interest taught by highly competent teachers in utilizing ICT as a learning media

$\mu_{a 2}$ : The average student learning interest taught by teachers is of moderate competence in utilizing ICT as a learning medium

$\mu_{a 3}$ : The average student learning interest taught by teachers with low competence in utilizing ICT as a learning media

Based on the SPSS output that appears from the results of one-way ANAVA calculation in Table 4.17, it is obtained that the value of $F_{\text {hitun }}=40.205$ with a significant value of 0.000 $<0.05$. So the hypothesis testing results reject Ho and accept Ha. Thus, it can be concluded that there are significant differences between students' learning interests taught by highcompetency, middle and low competency teachers in utilizing ICT-based learning media.

\section{Discussion}

Based on the results of research obtained in this study, these results indicate that the competence of primary school teachers in utilizing ICT-based learning media in Banda Aceh is included in the medium category. To have the ability and expertise, teachers are required to constantly improve their knowledge, use and master technology, both computers and other technological tools that can be used in learning (Rusyan (2014: 27). In line with that Degeng (in Husain, 2014: 184) says the quality of learning can be seen from two aspects, namely aspects of the process and learning outcomes. While efforts to improve the quality of the learning process lead to the emergence of initiatives from both students and educators.In connection with the quality of learning as stated by the Degeng, Miarso (in Husain, 2014: 184) says the factors that influence or support the realization of the learning process quality in an effort to achieve educational goals one of which is the use or use of information and communication technology in the process of education and learning.

Based on the results of the research obtained, it can be seen that the average student learning interest taught by highly competent teachers in utilizing ICT-based learning media is higher than the average student learning interest taught by moderate-competent teachers with differences in average to reaching 4,096. While the average student learning interest taught by high-competency teachers is higher than the average student learning interest taught by lowcompetency teachers, the average ratio reaches 10,564. Likewise, the average student learning interest taught by teachers with moderate competence is higher than the average student 
learning interest taught by low-competency teachers, with an average ratio of up to 6.468. The findings suggest that students' interest in learning will be greatly influenced by the teacher's ability to use the media. In this case the ICT media is not only able to support the learning process so that the creation of active learning, but by utilizing ICT as a medium in the learning process properly and correctly can increase students' interest in learning. The use of appropriate learning media will influence the effectiveness of learning in the classroom (Wirdaningsih \& Mardhatillah, 2016)

\section{Conclusion}

The ability of elementary school teachers to utilize ICT-based learning media in Banda Aceh City is in the moderate category, the total score obtained is $170.22(140 \leq X<220)$. There is a significant difference between the average student interest in learning taught by teachers who have high, moderate and low competence in using ICT as a learning media (sig. 0,000 $<0,05)$.

\section{References}

Anzar, S. F., \& Mardhatillah, M. (2018). Analisis Kesulitan Belajar Siswa pada Pembelajaran Bahasa Indonesia di Kelas V SD Negeri 20 Meulaboh Kabupaten Aceh Barat Tahun Ajaran 2015/2016. Bina Gogik, 4(1).

Bataineh, R. Fahmi, dkk. 2018. The effect of e-mail and WhatsApp on Jordanian EFL learners' paraphrasing and summarizing skills. International Journal of Education and Development using Information and Communication Technology (IJEDICT). 14 (3): 131-148.

Halidi, Hasan Mahmud. 2015. Pengaruh Media PembelajaranBerbasis TIK terhadapMotivasidanHasilBelajar IPA SiswaKelas V SDN Model TerpaduMadaniPalu. e-JurnalMitraSains. 3 (1): 53-60.

Husain, Chaidar. 2014. PemanfaatanTeknologiInformasidanKomunikasidalamPembelajaran di SMA MuhammadiyahTarakan.JurnalKebijakandanPengembanganPendidikan.2 (2): 184-192.

Mardhatillah, M., \& Trisdania, E. (2018). Pengembangan Media Pembelajaran Berbasis Macromedia Flash untuk Meningkatkan Kemampuan Membaca Siswa di SD Kelas II Negeri Paya Peunaga Kecamatan Meureubo. Bina Gogik, 5(1).

Mayer, Richard. E. 2009. Multimedia Learning.Second edition.New York: Cambridge University Press.

Mbodila, Munienge. 2013. Integration of ICT in Education: Key Challenges. International Journal of Emerging Technology and Advanced Engineering. 3 (11): 515-520.

Miarso, Yusufhadi. 2005. Menyemai Benih Teknologi Pendidikan. Jakarta: Kencana.

Rosdiana. 2016. Penggunaan Media Pembelajaran Berbasis ICT Dan Pengaruhnya Terhadap Tingkat Kelulusan Ujian Nasional Siswa Pada Sekolah Menengah Di Kota Palopo (Studi Kasus Di 5 Sekolah Menengah Di Kota Palopo). Jurnal Pendidikan Matematika dan Ilmu Pengetahuan Alam. 4 (1): 73-88.

Rusman, D. Kurniawan, C. Riyana. 2015. Pembelajaran Berbasis Teknologi Informasi dan Komunikasi. Mengembangkan Profesionalitas Guru. Jakarta: Rajawali Pers. 
Rusyan, H.A. Tabrani (Ed.) 2014. Membangun Guru Berkualitas. Jakarta: PT. Pustaka Dinamika.

Schramm. Wilbur L. 1907. Big Media Little Media (People and Communication). Amerika Serikat: Sage Publications INC.

Sudatha. I. G. Wawan. 2014. Peningkatan Kompetensi Guru Melalui Pelatihan Merancang Pembelajaran Terintegrasi Teknologi Informasi Dan Komunikasi (TIK) Pada Guru-Guru

SMP Di Kecamatan Buleleng. Seminar Nasional Teknologi Pembelajaran, 22-29.

Sumiarsi, Ninik. 2015. Analisis Kompetensi Pedagogik dan Pengembangan Pembelajaran Guru SD Negeri 041 Tarakan. Jurnal Kebijakan dan Pengembangan Pendidikan. 3 (1): 99-104.

Tanjung, Samsidar. 2015. Pengaruh Media Pembelajaran dan Gaya Kognitif Terhadap Hasil Belajar Sejarah. Paramita. 25 (2): 261.

Wirdaningsih, W., \& Mardhatillah, M. (2016). Penerapan Media Audio-Visual Terhadap Keaktifan Pada Materi Hubungan Antara Sumber Daya Alam Dengan Lingkungan Siswa Kelas IV SD Negeri Pasi Teungoh Kecamatan Kaway XVI. Bina Gogik, 3(2). 